\title{
Hang Tuah as a Malay warrior from the perspective of the younger Malaysian generation
}

\begin{abstract}
This paper is aimed at assessing the relevance of Hang Tuah as a warrior figure for contemporary society, especially the younger generation in this country, represented by students of Universiti Putra Malaysia. Since the 15th century, Hang Tuah has been synonymous with a warrior who symbolizes the strength, excellence and greatness of the Malay community in all aspects of life. This recognition of Hang Tuah as a warrior has been handed down from generation to generation until today. However, in Malaysia's rapid pursuit to be a modern nation in the 21 st century, the relevance of this element of a 'cultural warrior' for fulfilling the demand for a social 'icon' of today is doubtful. Questions revolve as to whether the existence of Hang Tuah is still necessary and whether he is still accepted, especially by the younger generation. Therefore, by using a qualitative method, 80 students from Universiti Putra Malaysia were interviewed using a structured questionnaire as the research tool. The students were aged between 21 to 24 years and were divided equally into 40 students with a literature background and 40 students with a non-literature background. To evaluate the relevance of Hang Tuah as a warrior for the younger generation of today, the respondents were asked two main questions to gauge their knowledge about Hang Tuah and their perspective of the his existence, validity, heroism and skills as a Malay warrior. The results of the study showed that Hang Tuah is still relevant and is still accepted as a 'cultural warrior' by the present generation. This directly gives the impression that Hang Tuah is still needed by the present generation and that he does not need to be replaced by other figures as changes take place in time.
\end{abstract}

Keyword: Culture; Hikayat Hang Tuah; Malay; Sejarah Melayu; Warrior 